\title{
Effect of Timber Harvest Intensities and Fertilizer Application on Stocks of Soil C, N, P, and S
}

\author{
Marcella L.C. Menegale ${ }^{1, *}$, Jose Henrique T. Rocha ${ }^{2}$, Robert Harrison ${ }^{1}$, \\ Jose Leonardo de M. Goncalves ${ }^{2}$, Rodrigo F. Almeida ${ }^{3}$, Marisa de C. Piccolo ${ }^{3}$, Ayeska Hubner ${ }^{2}$, \\ Jose Carlos Arthur Junior ${ }^{4}$, Alexandre de Vicente Ferraz ${ }^{5}$, Jason N. James ${ }^{1}$ and \\ Stephani Michelsen-Correa ${ }^{1}$ \\ 1 School of Environmental and Forest Sciences, University of Washington, Seattle, WA 98195-2100, USA; \\ robh@uw.edu (R.H.); jajames@uw.edu (J.N.J.); smcorrea@uw.edu (S.M.-C.) \\ 2 Forest Science Department, "Luiz de Queiroz" College of Agriculture, University of São Paulo, \\ Piracicaba SP 13418-900, Brazil; rocha.jht@gmail.com (J.H.T.R.); jlmgonca@usp.br (J.L.d.M.G.); \\ ayeskahubner@yahoo.com.br (A.H.); \\ 3 Center of Nuclear Energy in Agriculture, University of São Paulo, Piracicaba, São Paulo 13416-000, Brazil; \\ rodrigo.fa18@gmail.com (R.F.A.); mpiccolo@cena.usp.br (M.d.C.P.) \\ 4 Federal Rural University of Rio de Janeiro, Seropédica, Rio de Janeiro 23890-000, Brazil; jcarthur@ufrrj.br \\ 5 Forest Science and Research Institute (IPEF), Piracicaba, São Paulo 13400-970 Private Bag 530, Brazil; \\ alexandre@ipef.br \\ * Correspondence: marcism@uw.edu; Tel.: +1-206-209-6421
}

Academic Editors: Scott X. Chang and Xiangyang Sun

Received: 12 September 2016; Accepted: 12 December 2016; Published: 21 December 2016

\begin{abstract}
The purpose of this study was to determine the stocks of available P and S, total N, and oxidizable $\mathrm{C}$ at depth in an Oxisol cultivated with Eucalyptus in Brazil following different timber harvest intensities and fertilizer application over 12 years. The harvest regimes considered were (i) conventional stem-only harvest (all forest residues were maintained on the soil); (ii) whole-tree harvest (only litter was maintained on the soil—all slash, stemwood, and bark were removed); and (iii) whole-tree harvest + litter layer removal. The site was planted in 2004 considering three timber harvest intensities, some with and some without $\mathrm{N}$ and $\mathrm{P}$ fertilization. In 2012 the experiment was reinstalled, and all the treatments were reapplied in the each plot. From 2004 to 2016, nutrient accumulation and soil N, P, and S stocks were assessed in the 0-20 cm layer. Also in 2016, soil N, P, S, and oxidizable $C$ stocks were measured to $2 \mathrm{~m}$ depth. For each treatment, the net balance of $\mathrm{N}, \mathrm{P}$, and $\mathrm{S}$ were calculated from soil stocks and harvest outputs during two forest rotations. A reduction in all nutrient stocks was observed in the 0-20 cm layer for all treatments. For $\mathrm{N}$, this reduction was $20 \%$ smaller in the stem-only harvest treatment and $40 \%$ higher when no $\mathrm{N}$ fertilizer was applied, when compared to other treatments. Stem-only harvest treatment was observed to reduce the loss of $\mathrm{N}$, $\mathrm{P}$, and S due to harvest by 300,30 , and $25 \mathrm{~kg} \cdot \mathrm{ha}^{-1}$, respectively, when compared to the whole-tree harvest + litter layer removal treatment.
\end{abstract}

Keywords: nutrient cycling; forest residue management; Eucalyptus; nitrogen; carbon; phosphorus; sulfur; minimum tillage

\section{Introduction}

Forest soils form an important reservoir in ecosystem nutrient and carbon budgets, which are crucial for the sustained productivity of forests [1]. Nutrient fluxes and transformations in forest soils are a result of a complex interchange between the atmosphere, plants, and soil. Consequently, soils are a critical source of plant nutrition [2], and integral to the recovery of ecosystems following natural or human disturbances. As essential plant nutrients, the concentrations of plant available nitrogen $(\mathrm{N})$, 
phosphorous $(\mathrm{P})$, and sulfur $(\mathrm{S})$ are crucial controls on the net primary productivity of a site. As the plants uptake these nutrients, their concentrations within the soil are reduced until they are replaced either by nutrient recycling or fresh inputs. In order to maintain the supply of these nutrients back into the soil, sustainable silviculture practices focus on high timber productivity while efficiently balancing the additional export of harvest residues with the cost of fertilizer to replace nutrients.

Highly weathered tropical soils are characteristically deficient in essential plant nutrients. This is especially true of the macronutrients essential for plant growth and development [3]. Organic matter $(\mathrm{OM})$ plays a fundamental role in soil fertility, contributing to cation exchange capacity (CEC) and as a source of nutrients [4], while also stabilizing soil aggregates and increasing water holding capacity. Soil management practices can sustain adequate levels of $\mathrm{OM}$ while providing sufficient quantities of plant available $P$. The need for balancing high timber productivity while maintaining soil nutrient concentrations has led to the development of sustainable silvicultural practices $[5,6]$.

Highly weathered soils may conserve more carbon (C) with increasing OM inputs because $\mathrm{P}$ frequently limits decomposition [7]. Such $\mathrm{P}$ limitations will also effect microbially driven processes, such as $\mathrm{N}$ mineralization. While most temperate ecosystems-which are usually $\mathrm{N}$ limited-may store added mineral $\mathrm{N}$ for long periods, a $\mathrm{P}$ limited tropical forest can rapidly loose substantial amounts of mineral $\mathrm{N}\left(\mathrm{NO}_{3}{ }^{-}\right.$and $\left.\mathrm{NH}_{4}{ }^{+}\right)$following $\mathrm{N}$ fertilization [8]. The nutrient limitations of tropical soils not only decrease plant productivity but also impact decomposition rates and immobilization processes and therefore the soil's capacity to store and cycle $C$ and $N$ [9-11].

Many consider the proper management of forest residues to be a practice which maintains the harvest residues (i.e., slash, bark, and litter layer) on site as a source of nutrients. The practice of leaving forest residues on site can sustain soil quality with respect to the productivity of medium and long-term species such as Eucalyptus [12-16]. This practice helps to improve nutrient pools and OM content in the soil [3]. Harvest residues, when retained on site, deposit nutrients back to the soil following decomposition. Plants cultivated in the area will then readily absorb these nutrients. This reduces the need for synthetic fertilizer and other methods for soil preparation that can disrupt soil physicochemical properties such as aggregation $[17,18]$. In addition, the protective layer formed due to the presence of harvest residues on the soil helps to reduce extreme surface heating and water loss through evaporation, and decreases soil loss due to erosion.

Due to the coupling of soil nutrient status (i.e., C, N, P, and S) and forest productivity, elucidating the impacts of forest residue additions will aid in the sustainable management of high quality, rapidly growing timber crops. Under tropical conditions, it is still unclear how the presence of harvest residues in the soil can help to create a more efficient silviculture system with regards to productivity, improved preservation of soil characteristics, and reduced fertilizer applications. For this reason, the objective of this study was to determine the stocks of available $P$ and $S$, total $N$, and oxidizable $C$ at depth in an Oxisol which was cultivated with Eucalyptus in Brazil over 12 years, under different timber harvest intensities and fertilizer applications. During each forest rotation the net balance between soil N, P, and $\mathrm{S}$ stocks and harvest outputs was also calculated.

\section{Materials and Methods}

\subsection{Study Site}

The study was carried out at the Itatinga Forest Science Experimental Station of the University of São Paulo in Brazil ( $23^{\circ} 06^{\prime} \mathrm{S}, 48^{\circ} 36^{\prime} \mathrm{W}$, and $857 \mathrm{~m}$ above sea level). The Köppen climate classification of the site is humid subtropical ( $\mathrm{Cfa}$ ) with an average annual temperature of $19.4{ }^{\circ} \mathrm{C}$. In the coldest month (July), the temperatures average $15.6^{\circ} \mathrm{C}$, and in the hottest month (January), the temperatures average $22.3{ }^{\circ} \mathrm{C}$. The mean annual rainfall is $1319 \mathrm{~mm}$, with $75 \%$ of the rainfall concentrated between October and March [19].

The topography of the region is flat to undulating, and the soil is a very deep $(>10 \mathrm{~m})$ Ferralsol (International Union of Soil Sciences (IUSS) Working Group-World Reference Base for 
Soil Resources (WRB), 2015; red-yellow Latosol—Brazilian Classification System, and Oxisols—United State Department of Agriculture (USDA) Soil Taxonomy) that developed on Cretaceous sandstone. The clay content ranges from $17 \%$ in the A1 horizon to $25 \%$ in deeper Bo horizons. The mineralogy was dominated by quartz, kaolinite, and oxyhydroxides of $\mathrm{Al}$ and $\mathrm{Fe}$ with a low $\mathrm{pH}$ and small amounts of exchangeable cations (Table 1).

Table 1. Physical and chemical attributes of experimental site *

\begin{tabular}{|c|c|c|c|c|c|c|c|c|c|c|c|c|}
\hline \multirow{2}{*}{ Depth } & \multirow{2}{*}{ Sandy } & \multirow{2}{*}{ Silt } & \multirow{2}{*}{ Clay $^{1}$} & \multirow{2}{*}{$\mathrm{pH}^{2}$} & \multirow{2}{*}{$\mathrm{CEC}_{7}{ }^{3}$} & \multirow{2}{*}{$C^{4}$} & \multirow{2}{*}{$\mathbf{N}^{5}$} & \multirow{2}{*}{$P^{6}$} & \multicolumn{4}{|c|}{ Exchangeable Cations $^{4}$} \\
\hline & & & & & & & & & $\mathbf{K}$ & $\mathrm{Ca}$ & Mg & Al \\
\hline $\mathrm{cm}$ & & $\mathbf{g} \cdot \mathbf{k g}^{-1}$ & & & $\operatorname{mmol}_{\mathbf{c}} \mathbf{k g}^{-1}$ & \multicolumn{2}{|c|}{$\mathbf{g} \cdot \mathbf{k g}^{-1}$} & $\mathrm{mg} \cdot \mathrm{kg}^{-1}$ & \multicolumn{4}{|c|}{$\mathbf{m m o l}_{\mathbf{c}} \mathbf{k g}^{-1}$} \\
\hline $0-10$ & 802 & 22 & 175 & 3.8 & 63.98 & 9.61 & 1.44 & 4 & 0.25 & 4.28 & 2.81 & 7.50 \\
\hline $10-20$ & 811 & 12 & 176 & 3.9 & 51.42 & 10.05 & 1.67 & 3 & 0.27 & 2.80 & 2.17 & 8.43 \\
\hline $20-30$ & 790 & 34 & 176 & 3.9 & 39.98 & 6.77 & 1.53 & 1 & 0.20 & 1.32 & 1.00 & 6.09 \\
\hline $30-40$ & 777 & 23 & 200 & 3.9 & 40.18 & 5.33 & 1.29 & 1 & 0.15 & 0.88 & 0.81 & 7.03 \\
\hline $40-60$ & 747 & 14 & 239 & 3.9 & 38.46 & 5.42 & 1.14 & 1 & 0.15 & 0.99 & 0.72 & 7.50 \\
\hline $60-100$ & 712 & 12 & 276 & 3.9 & 32.72 & 5.04 & 0.99 & 1 & 0.15 & 0.66 & 0.54 & 6.56 \\
\hline $100-150$ & 712 & 11 & 277 & 4.0 & 30.09 & 3.44 & 1.04 & 1 & 0.08 & 0.71 & 0.54 & 2.34 \\
\hline $150-200$ & 704 & 20 & 276 & 4.2 & 22.05 & 0.87 & 1.04 & 1 & 0.05 & 0.55 & 0.54 & 2.81 \\
\hline
\end{tabular}

* Samples were taken in 2014. The total area of the experiment was considered (average of all plots). ${ }^{1}$ Pipette method; ${ }^{2}$ Determined in $\mathrm{CaCl}_{2} 0.01 \mathrm{~mol} \cdot \mathrm{L}^{-1}$ in soil/solution reason of $1: 5 ;{ }^{3}$ Cation exchange capacity with soil at $\mathrm{pH} 7 ;{ }^{4}$ wet oxidation; ${ }^{5}$ Determined using the micro Kjeldahl method after sulphuric digestion; ${ }^{6}$ Extracted with exchange ion resin [20].

The original vegetation of the site was Cerrado stricto sensu (Brazilian savannah) [21]. The site has been planted with Eucalyptus species since 1940. From 1940 to 1992, it was cropped with Eucalyptus saligna and managed by coppicing with clearcutting every seven or eight years. In 1992, the plantation was harvested and replanted with Eucalyptus grandis, which was harvested (via clear-cutting) in 2004 when the study site was installed.

\subsection{Experimental Design and Treatments}

The study site was installed in 2004 (R1) and reinstalled in 2012 (R2) with three replicates of five treatments in a randomized block design. The plot sizes were $27 \mathrm{~m} \times 18 \mathrm{~m}$, with 81 trees per plot. The assessments were carried out in an inner plot of $15 \mathrm{~m} \times 10 \mathrm{~m}$ (25 trees per plot). Five treatments were implemented with different management levels of forest residue removal and fertilizer applications (Table 2). The forest residues manipulated in this experiment include all of the organic residues remaining on the soil after wood harvesting of $E$. grandis plantations after 12 years of growth: the leaves and branches less than $3 \mathrm{~cm}$ in diameter (canopy), bark, and litter layer. The treatments tested were:

1. ReM + F-Only stemwood was harvested; all of the forest residues (bark, canopy, and litter layer from the previous rotation) were maintained on the soil after the clear-cutting, and all nutrients were applied as fertilizer and the soil was dressed with limestone;

2. ReR $+F-$ All of the forest residues (bark, canopy, and litter layer from the previous rotation) were removed from the plot after the clear-cutting, and all nutrients were applied as fertilizer and the soil was dressed with limestone;

3. ACR $+\mathrm{F}$ - The canopy (leaves and branches) and bark were removed after clear-cutting, but the litter layer was maintained; all nutrients were applied as fertilizer and the soil was dressed with limestone;

4. ACR - N-The canopy (leaves and branches) and bark were removed after the clear-cutting, but the litter layer was maintained; all nutrients except $\mathrm{N}$ fertilizer were applied and the soil dressed with limestone. However, a small quantity of $\mathrm{N}$ was applied to ensure tree survival;

5. ACR - P-The canopy (leaves and branches) and bark were removed after the clear-cutting, but the litter layer was maintained; all nutrients except $P$ fertilizer were applied and the soil was dressed with limestone; 
Table 2. Forest residue management and nutrients applied in treatments.

\begin{tabular}{|c|c|c|c|c|c|c|c|c|c|}
\hline \multirow{2}{*}{ Treatment $^{1}$} & \multicolumn{3}{|c|}{ Forest Residue $^{2}$} & \multicolumn{6}{|c|}{ Nutrients ${ }^{3}$} \\
\hline & Canopy & Bark & Litter Layer & $\mathbf{N}$ & $\mathbf{P}$ & $\mathbf{K}$ & $\mathrm{Ca}$ & $\mathrm{Mg}$ & $\mathrm{S}$ \\
\hline & & & & \multicolumn{6}{|c|}{$\mathrm{kg} \cdot \mathrm{ha}^{-1}$} \\
\hline $\operatorname{ReM}+\mathrm{F}$ & M & M & M & 130 & 44 & 125 & 480 & 120 & 140 \\
\hline $\operatorname{Re} R+F$ & $\mathrm{R}$ & $\mathrm{R}$ & $\mathrm{R}$ & 130 & 44 & 125 & 480 & 120 & 140 \\
\hline $\mathrm{ACR}+\mathrm{F}$ & $\mathrm{R}$ & $\mathrm{R}$ & M & 130 & 44 & 125 & 480 & 120 & 140 \\
\hline $\mathrm{ACR}-\mathrm{N}$ & $\mathrm{R}$ & $\mathrm{R}$ & M & 10 & 44 & 125 & 480 & 120 & 11 \\
\hline$A C R-P$ & $\mathrm{R}$ & $\mathrm{R}$ & M & 130 & - & 125 & 480 & 120 & 140 \\
\hline
\end{tabular}

${ }^{1}$ Detailed description in Material and Methods; ${ }^{2} \mathrm{M}=$ maintained on the soil, $\mathrm{R}=$ removed from the area;

${ }^{3} \mathrm{~N}, \mathrm{P}, \mathrm{K}, \mathrm{Ca}$ and $\mathrm{Mg}$ sources were ammonium sulphate, triple superphosphate, potassium chloride, and limestone, respectively.

The ReR + F treatment was included to simulate a severe harvest condition where all forest residues were removed from the site, with fertilization being the only source of nutrients added to the soil. Although unusual, this harvest management system has already been implemented in some regions in Brazil, especially when biomass prices were high and all forest residues were removed with the objective of maximizing biomass production. Furthermore, by examining such an extreme treatment, this study brackets the range of harvest intensities actually utilized by different forest managers. Thus, the effects of more moderate treatments can be estimated by interpolating between two endmembers rather than extrapolating from a more limited range of harvest intensity.

\subsection{Field Procedures}

After clear-cutting the 12-year-old Eucalyptus grandis Hill Ex Maiden plantation, the treatments (Table 2) were applied and the soil was prepared by subsoiling to $0.4 \mathrm{~m}$ deep with a ripper. The plots were planted with a single progeny of E. grandis Hill ex Maiden seedlings in June 2004 (one month after harvesting the previous plantation). The fertilizer that was applied is shown in Table 2. Additionally, $3.4 \mathrm{~kg} \cdot \mathrm{ha}^{-1}$ of boron (B) and $30 \mathrm{~kg} \cdot \mathrm{ha}^{-1}$ of Fritted Trace Elements (FTE) $(9 \% \mathrm{Zn}, 1.8 \% \mathrm{~B}, 0.8 \% \mathrm{Cu}$, $2 \% \mathrm{Mn}, 3.5 \% \mathrm{Fe}$, and $0.1 \% \mathrm{Mo}$ ) were applied in every treatment. The fertilizer was applied as one base fertilizer application and two topdressing applications. The base fertilizer application was made on the same day as the planting, the triple superphosphate, the FTE, and $10 \mathrm{~kg} \cdot \mathrm{ha}^{-1}$ of $\mathrm{N}$ and $\mathrm{K}$ were added in a small pit to the side of each seedling, whereas the lime $\left(2 \mathrm{Mg} \cdot \mathrm{ha}^{-1}\right)$ was applied to the whole area. The ACR $-\mathrm{N}$ treatment received a small amount of $\mathrm{N}$ with the base fertilizer to ensure the survival and the initial development of plants. The topdressing application of $\mathrm{N}, \mathrm{K}, \mathrm{S}$ and $\mathrm{B}$ was applied around the seedling within the ground area covered by the canopy at three and eight months after planting. The plantation was harvested at eight years of age and replanted one month later (November 2012). The treatments were repeated at each plot (Table 2).

During clear-cutting, the canopy and bark from the trees of each plot were retained on the same plots. The clear-cut trees were felled with a chainsaw; the bark and branches were then removed manually. The seedlings in R2 were planted between the stumps of R1 without ripping. R2 was managed in the same way as R1 to evaluate the long-term effects of the residue removal and fertilizer application practices. Each experimental unit was maintained weed free throughout the two rotations.

\subsection{Soil Sampling and Analysis}

Soil samples were collected before the application of the treatments in the first (2004) and second (2012) rotations at $0-10$ and $10-20 \mathrm{~cm}$. In 2016, samples were taken from the soil down to two meters $(0-10,10-20,20-40,40-60,60-80,80-100,100-150$, and 150-200 cm) across three replications for each treatment. Each sample was composed of six subsamples taken from six points in the inner plot arranged in a diagonal design. For each plot, soil bulk density was calculated from soil samples taken from the walls of trenches opened with known volume rings. 
Samples were then air-dried at $45^{\circ} \mathrm{C}$ for three days and passed through a $2 \mathrm{~mm}$ sieve for chemical analysis. Soil analyses were carried out for all treatments. Total $\mathrm{N}$ was determined by dry combustion using an Elemental Analyzer CHNS/2400 (Perkin Elmer, Waltham, MA USA) [22]. Available P was determined by displacement using ion-exchange resins. Sulfur was displaced with $\mathrm{Ca}\left(\mathrm{H}_{2} \mathrm{PO}_{4}\right)_{2}$ $0.01 \mathrm{~mol} \cdot \mathrm{L}^{-1}$ solution and determined by turbidimetry using $\mathrm{BaSO}_{4}$ [20]. Oxidizable $\mathrm{C}$ was determined by wet oxidation [23].

\subsection{Nutrient Accumulation in the Biomass}

In order to assess the accumulation of nutrients in the biomass (canopy, bark, wood, and coarse roots), 10 trees were felled in 2004, 10 trees per treatment were felled in 2012, and 3 trees per treatment were felled in 2016, with all removed trees coming from the inner border of each plot. Felled trees were separated into the following compartments: leaves, branches, stemwood (diameter $>3 \mathrm{~cm}$ at the thinner end), and stem bark. Coarse root (diameter $>1 \mathrm{~cm}$ ) was removed by excavation. Sub-samples were collected from all of the compartments and dried $\left(65^{\circ} \mathrm{C}\right)$ until reaching a constant weight, and then the dry biomass of the compartments in each tree was proportionally calculated. To estimate the wood, bark biomass, and stem volume of the plantation from the sampled trees, diameter at breast high (DBH) and total high $(\mathrm{H})$ were used as independent variables to adjust a model following the form of Schumacher and Hall [24].

Samples were analyzed for N, P, and S. Total N was determined using the micro Kjeldahl method after sulphuric digestion. $\mathrm{P}$ was determined through colourimetry after nitric perchloric digestion, and $\mathrm{S}$ was determined through turbidimetry [25]. Nutrient accumulation per hectare was determined by the sum of the product of biomass accumulation of each compartment and the nutrient concentrations.

\subsection{Statistical Analysis}

Prior to statistical analysis, the data were tested for normality (Shapiro-Wilk) and homoscedasticity (Box-Cox). A two-way Analysis of Variance (ANOVA) test was performed to identify the differences between the factors considered in the experiment (soil depth and treatment). Equal sample sizes were used in order to obtain maximum power and robustness of the test. In the case of overall significant differences in the group means, Fisher's Least Significant Difference (LSD) post hoc testing was performed to determine the differences between groups [26]. Statistical tests were considered significant at $\alpha=0.05$. Data was analyzed using SAS University Edition (University Edition, SAS Institute Inc., Cary, NC, USA).

\section{Results}

\subsection{Nutrient Balance After Two Crop Rotations}

Before the installation of the experiment in 2004, the site contained 370, 11, and $9.2 \mathrm{~kg} \cdot \mathrm{ha}^{-1}$ of N, $\mathrm{P}$, and S, respectively, in the 0-20 cm layer (Figure 1). On that occasion, there was an accumulation of approximately 660,90 , and $100 \mathrm{~kg} \cdot \mathrm{ha}^{-1}$ of $\mathrm{N}, \mathrm{P}$, and S, respectively, in the biomass and litter layer (250 $\mathrm{t} \cdot \mathrm{ha}^{-1}$ in total). The nutrient losses following harvest within the ReR $+\mathrm{F}$ treatment were higher than that of the ReM + F treatment by $120 \%, 50 \%$, and $40 \%$ of N, P, and S respectively. For the ACR treatments, the losses from harvest were $65 \%, 30 \%$, and $20 \%$ higher, respectively, than the ReM + F treatment (Table 3).

In 2012 (the end of experiment's first rotation), the ReM + F treatment contained the largest stocks of $\mathrm{N}\left(206 \mathrm{~kg} \cdot \mathrm{ha}^{-1}\right)$ and $\mathrm{P}\left(13.8 \mathrm{~kg} \cdot \mathrm{ha}^{-1}\right)$ in the $0-20 \mathrm{~cm}$ layer, while the highest stocks of S $\left(13.2 \mathrm{~kg} \cdot \mathrm{ha}^{-1}\right)$ for this layer were observed in the ACR - P treatment. The lowest stocks of N $\left(151 \mathrm{~kg} \cdot \mathrm{ha}^{-1}\right)$ and $\mathrm{P}(9$ $\mathrm{kg} \cdot \mathrm{ha}^{-1}$ ) were observed in the ACR $-\mathrm{N}$ and ACR $-\mathrm{P}$ treatments, respectively (Figure 1).

At the end of the first rotation of the experiment (eight years) there were no observed differences in the volume of wood produced in the treatments ReM $+F, A C R+F, R e R+F$, and ACR - N, which were about $420 \mathrm{~m}^{3} \cdot \mathrm{ha}^{-1}$ on average. On the other hand, the absence of fertilization with P (ACR - P 
treatment) resulted in approximately a $10 \%$ reduction in the final wood volume [27]. Even with small differences in tree growth, the renewal of the experiment for the next crop rotation resulted in great differences in the quantity of nutrient losses among the treatments, due to the different parts of the plants removed at harvest (Table 3).

At 41 months into the second rotation, the ReM + F treatment contained $100 \mathrm{Mg} \cdot \mathrm{ha}^{-1}$ of biomass (wood, bark, canopy, and coarse roots). Compared to the ReM + F treatment, the biomass accumulated in the ACR + F, ReR + F, ACR - N, and ACR - P treatments was lower by $14 \%, 15 \%, 16 \%$, and 25\%, respectively. The accumulated N, $\mathrm{P}$, and $\mathrm{S}$ in the biomass of the ACR - P treatment was $33 \%, 40 \%$, and $20 \%$ lower, respectively, compared to the ReM + F treatment.

Between 2004 and 2012, N contents in the soil from 0-20 cm depth were reduced by around 50\% with larger losses in the ACR - N treatment and smaller losses in the ReM+F treatment. From 2012 to 2016, a smaller reduction in soil N was observed, with the exception of the ACR - P treatment. Only small losses of available P were observed between 2004 and 2012, but greater losses occurred after reinstallation of treatments, especially for repeated removal of harvest residues (ReR $+F)$. In the $\mathrm{ACR}+\mathrm{F}$ treatment the concentration of available $\mathrm{P}$ in surface soil was constant through the years. A larger reduction was observed for the ReR $+F$ and ACR $-P$ treatments with losses of approximately $30 \%$ from 2004 to 2016. In regards to available S, a reduction in the ReR + F treatment from 2004 to 2012 was observed, and an increase was observed in the ACR - P treatment. For the other treatments, S stocks were constant. From 2012 to 2016, available S stocks improved for all treatments (Figure 1).

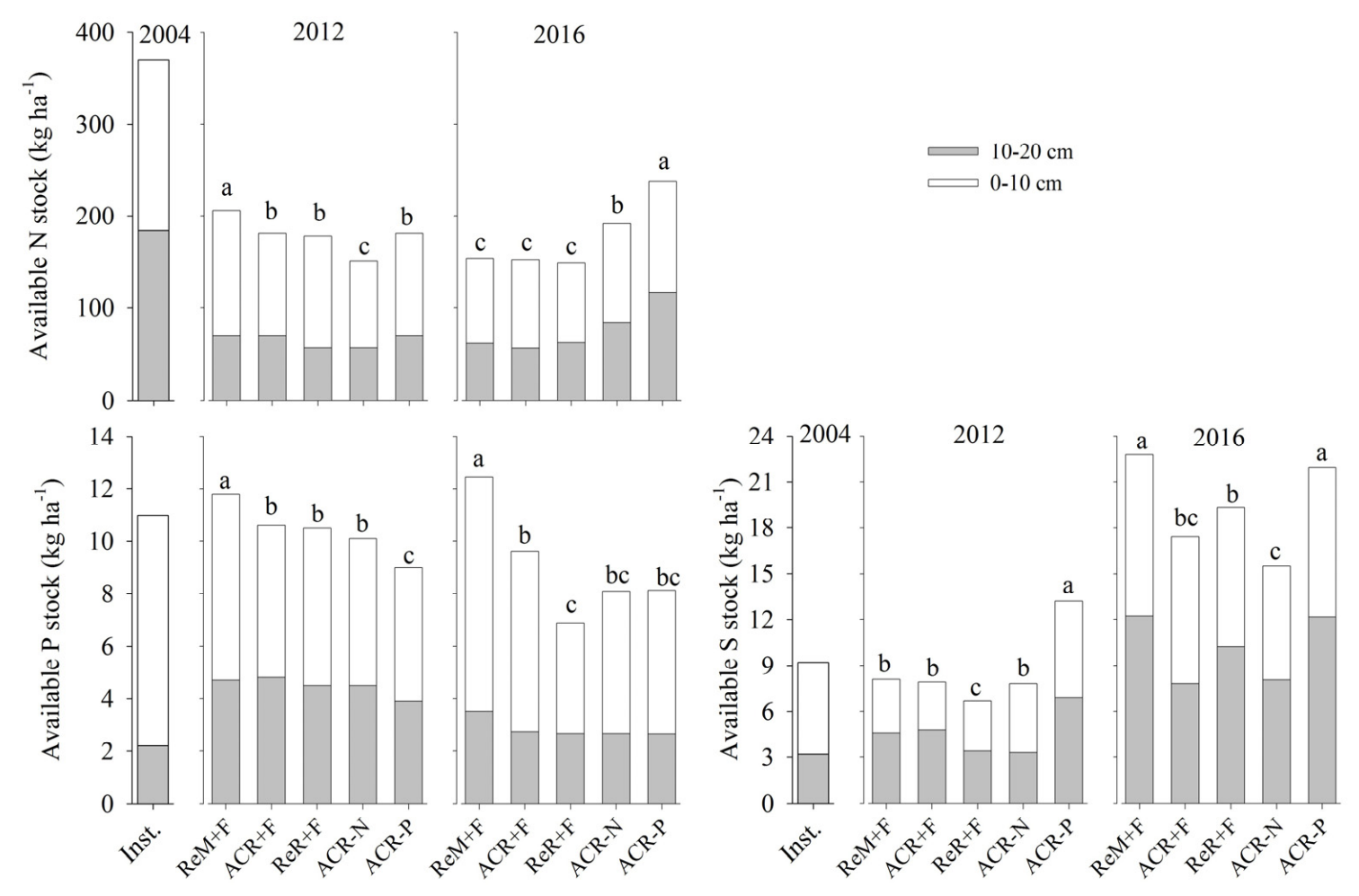

Figure 1. Available N, P, and S stocks in the $0-20 \mathrm{~cm}$ soil layer before the setup of treatments (2004), before the harvest of the first rotation (2012), and at four years into the second rotation (2016) in a Eucalyptus plantation under different harvest residue management and fertilizer application strategies. $\mathrm{P}$ was determined by resin extraction, $\mathrm{S}$ was determined by extraction with $\mathrm{Ca}\left(\mathrm{H}_{2} \mathrm{PO}_{4}\right)_{2}$ $0.001 \mathrm{~mol} \cdot \mathrm{L}^{-1}$, and available $\mathrm{N}$ was calculated assuming that $10 \%$ of total $\mathrm{N}$ is mineralizable [28]. Columns with the same letter are not significantly different from each other. 


\subsection{Soil Nutrient Stocks in 2016}

At four years into the second study rotation (2016), large differences between treatments were found in the stocks of Total N, Available P and S, and oxidizable C in the soil to $200 \mathrm{~cm}$ depth (Figure 2). The largest stock of oxidizable $C$ in the soil was observed in the ReM + F treatment $(p>0.001)$, and this treatment contained the most oxidizable $C$ at every individual sampling layer except between $60-100 \mathrm{~cm}$. The ReR + F treatment contained the lowest stocks of oxidizable C ( $p>0.002)$ up to $40 \mathrm{~cm}$ depth, and did not differ from the ACR treatments in the deeper layers. The supply of oxidizable carbon in the entire 0-200 cm profile of the ReM + F treatment was approximately $130 \mathrm{Mg} \cdot \mathrm{ha}^{-1}$, which is $10 \%$ greater than the ACR + F treatment and $20 \%$ higher than the ReR + F treatment.

The ACR-P treatment contained the highest stock of $\mathrm{N}(p>0.001)$ in all the layers considered. ReM $+F, A C R+F$, and ReR $+F$ treatments presented the lowest stocks of N, not differing statistically from each other. The ReR $+\mathrm{F}$ and ACR $-\mathrm{N}$ treatments presented the lowest stocks of $\mathrm{P}$, and were not significantly different. The stocks of $\mathrm{N}$ in the $0-200 \mathrm{~cm}$ layer of the soil were approximately $10 \mathrm{Mg} \cdot \mathrm{ha}^{-1}$ in the ReM + F, ACR + F, and ReR + F treatments. Stocks of available P in the soil were approximately $40 \mathrm{~kg} \cdot \mathrm{ha}^{-1}$ in the ReM $+\mathrm{F}$ and ACR $+\mathrm{F}$ treatments, which is $60 \%$ higher than the stock of P observed in the ReR + F treatment.

The ACR + F and ReR + F treatments contained the largest stocks of $\mathrm{S}$ in the soil $(p>0.001)$. The ACR $-\mathrm{N}$ and ACR $-\mathrm{P}$ treatments contained the lowest stocks of $\mathrm{S}(p>0.001)$. The stock of $\mathrm{S}$ available in the $0-200 \mathrm{~cm}$ layer was $280 \mathrm{~kg} \cdot \mathrm{ha}^{-1}$ in the ReM + F, ACR + F, and ReR + F treatments. The ACR - N treatment had a stock $30 \%$ lower than the previous treatments.

Table 3. Nutrient stocked in the forest biomass, inputs, and outputs of nutrients in two crop rotations.

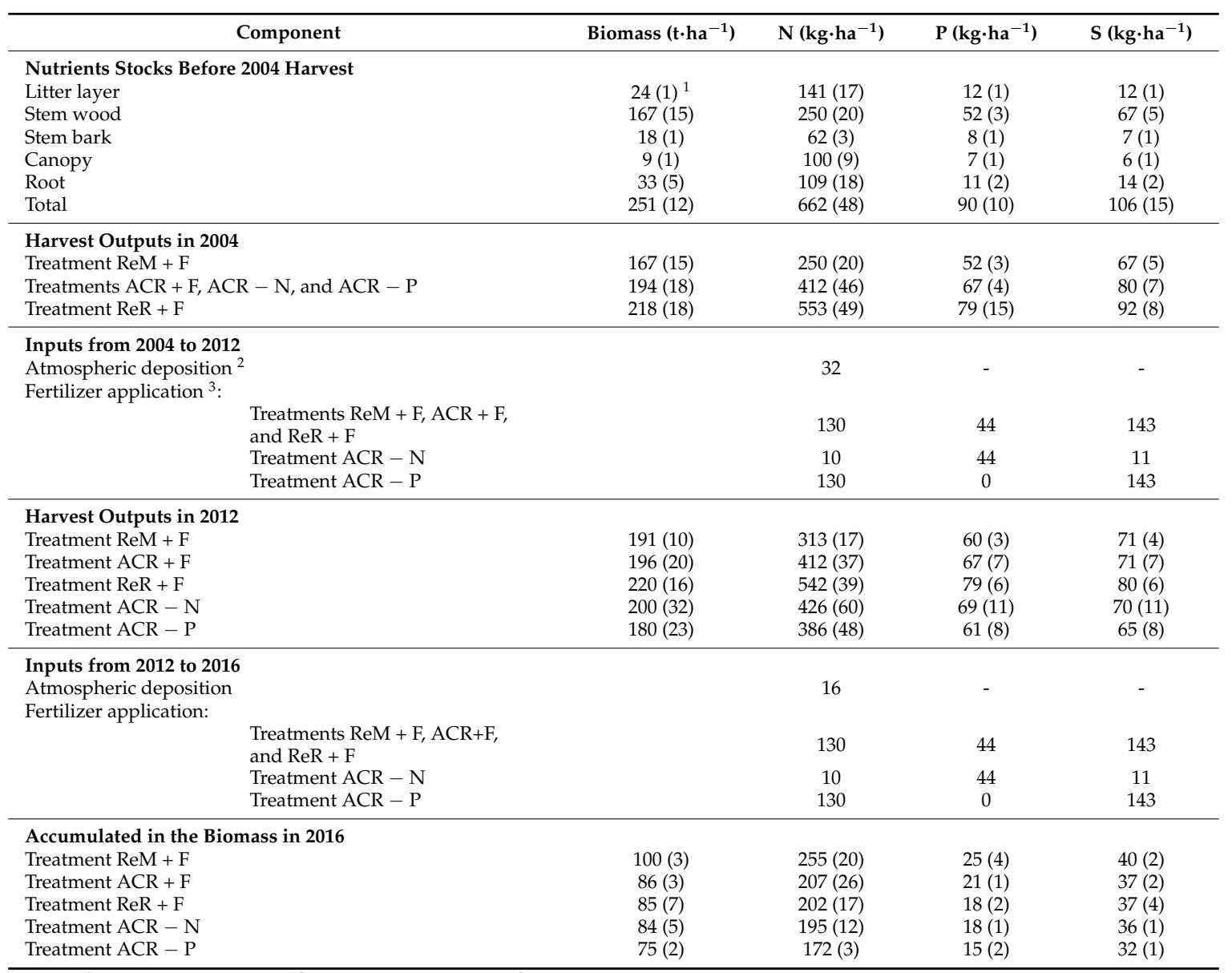

${ }^{1}$ Standard deviation; ${ }^{2}$ By Laclau et al. [29]; ${ }^{3}$ It is assumed that $100 \%$ of fertilizer application was available. 


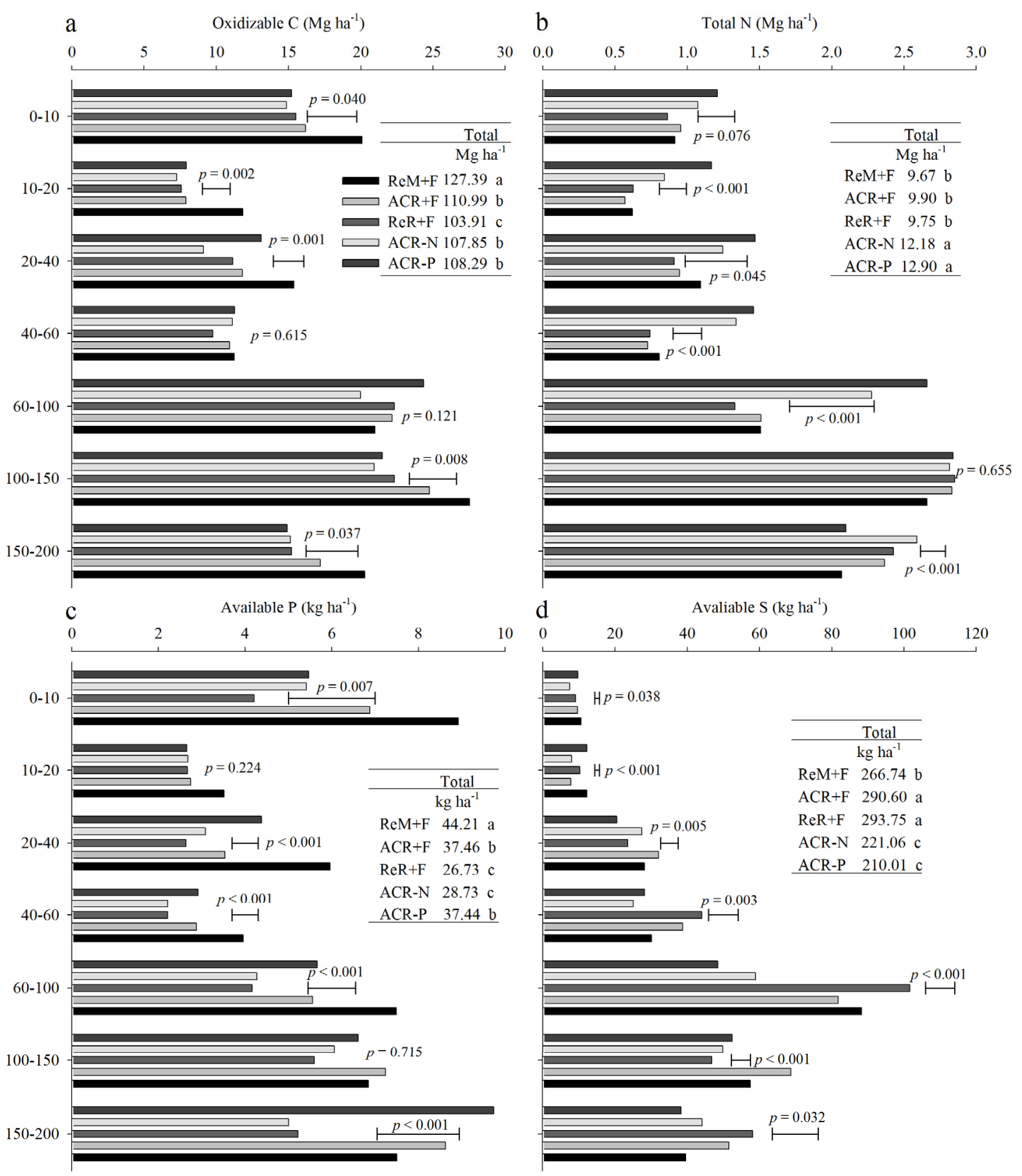

Figure 2. Stocks of oxidizable $C(\mathbf{a})$, total $\mathrm{N}(\mathbf{b})$, available $\mathrm{P}$ (c) and $\mathrm{S}$ (d) to $2 \mathrm{~m}$ depth in a Eucalyptus plantation under different harvest residue management and fertilizer application strategies. The bars indicate the least significant difference based on the Fisher's Least Significant Difference (LSD) test at $5 \%$ probability, and the values next to the bars show the significance of the $F$ test.

\section{Discussion}

\subsection{Effects of Harvest Residue Strategies on Soil C and Available Nutrient Stocks}

The effect of forest residue removal on soil nutrients stocks is inconsistent between different studies in the literature. In some cases, no losses in soil $\mathrm{C}$ or nutrient stocks have been reported, even with increases in nutrients exported during harvest [4,14,29-33]. This observation has been attributed to several mechanisms: high buffer capacity of the soil, slow decomposition of forest residues, a long harvesting return interval (more than seven years), and fast growth and litter deposition from new Eucalyptus plantations. However, reduction in soil C and nutrient stocks has 
been observed in wet tropical sites with sandy soils, high productivity forests, and successive harvest treatments [16,17,29,31,33]. Our study agrees with this latter set of studies and shows substantial changes in soil $\mathrm{C}$ and nutrients following removal of harvest residues.

In this study, the highest stocks of oxidizable $C$ in the soil were observed in the 0-20 cm soil layer of the ReM + F treatment, followed by ACR + F and ReR + F treatments $(p>0.001)$. Similar results were observed by Moreno-Fernandez et al. [34] in Mediterranean mountain Scots pine forests, where the highest stocks of $C$ were in the $0-20 \mathrm{~cm}$ layer of the soil under moderate intensity management.

Stocks of soil $\mathrm{C}$ decreased as soil depth increased, with the lowest stocks being observed in the ACR - P treatment $(p>0.006)$ at 150-200 cm depth. In a previous study developed in the same experimental site, Rocha [35] found that the removal of forest harvest residues from the soil reduces the oxidizable organic $C$ from the surface layer of the soil by $50 \%$, and $75 \%$ of this reduction happens in its labile fractions. Vanguelova et al. [36], on the other hand, concluded that there was no evidence that whole-tree harvest decreased soil organic C in a 28-year old second rotation stand of Sitka spruce in the UK. Slash removal has larger effects on soil C and nutrients when rotations are short, slash is removed repeatedly, clay content is low, temperatures are high, the site is relatively wet, and forest productivity is high [4,5]. It is well known that retaining harvest residues on the soil is extremely important to maintain high productivity of tropical forests [14-16]. However, more research is needed in order to reach a plausible conclusion about the subject due to the divergence in the data available, as observed by Nambiar and Harwood [14].

The forest residue removal for two rotations resulted in the cumulative loss of $23.5 \mathrm{t} \cdot \mathrm{ha}^{-1}$ of $\mathrm{C}$ from 0-200 cm soil depth (ReM + F and ReR + F treatments). This reduction was more concentrated in the top $40 \mathrm{~cm}$ (Figure 2). This effect is a result of the additional removal of $80 \mathrm{t} \cdot \mathrm{ha}^{-1}$ of biomass (slash and litter; 51 and $29 \mathrm{t} \cdot \mathrm{ha}^{-1}$ in $\mathrm{R} 1$ and R2, respectively) in the ReR + F treatment. Furthermore, the reduced initial growth in the ReR $+\mathrm{F}$ treatment during both rotations resulted in less litter deposition [27]. In the second rotation, a 40\% reduction in fine roots was observed in the $0-30 \mathrm{~cm}$ layer of the ReR $+\mathrm{F}$ treatment [37], which also contributed to low soil C content.

Forest residue removal resulted in a small reduction in the N stocks in the 0-20 cm layer in 2012 (Figure 1). However, no differences were observed between ReR + F and ReM + F treatments in 2016 (Figure 2) despite the higher harvest output in the ReR $+\mathrm{F}$ treatment. This can be attributed to the larger accumulation of $\mathrm{N}$ in the biomass in the ReM + F treatment, which was 33\% higher when compared to the ReR + F treatment. This aligns with other long-term productivity studies that find that subsequent tree growth following stem only harvest tends generally to be higher than whole-tree harvest due to the maintenance of harvest residues on the soil [38].

The available P stock was larger in the ReM + F treatment when compared with ReR + F treatment. This result could be caused by two main factors: (i) less ReM + F nutrient outputs by harvest and (ii) larger quantities of organic matter in ReM + F which reduces the fixation of P on the soil colloids, thus improving its availability. No differences were observed between treatments after $100 \mathrm{~cm}$ in depth. In a long-term productivity experiment conducted in North Wales, UK, by Walmsley et al. [9], the alterations in soil characteristics and their effects were tested using different harvest treatments (whole tree harvest and bole-only harvest) on 23-year-old second rotation stands of Sitka spruce (Picea sitchensis). The authors found that the whole-tree harvest treatment is responsible for the depletion of three to four times greater quantities of $\mathrm{N}, \mathrm{P}$, and $\mathrm{K}$ than the conventional bole-only harvest in the first rotation.

$\mathrm{ACR}+\mathrm{F}$ and $\mathrm{ReR}+\mathrm{F}$ treatments contained the largest stocks of $\mathrm{S}$ in the 40-100 cm layer in the soil, being statistically different when compared to others. This can be attributed to the lower concentration of soil organic C (SOC) of the previously mentioned treatments. Low organic matter $(\mathrm{OM})$ in highly weathered soils results in a higher quantity of positive charges, especially in the $\mathrm{B}$ horizon [39], with consequent retention of $\mathrm{SO}_{4}{ }^{2-}$ in the soil.

Repeated removal of forest harvest residues is likely to reduce oxidizable $\mathrm{C}$, available $\mathrm{N}$, and total P stocks in the soil under Eucalyptus plantations. The use of harvest residues as soil coverage 
can protect the soil against erosion, improve or maintain the SOC, and improve both the quantity and availability of nutrients stored in the soil [5,11,15].

\subsection{Soil Contribution to Nutrients Absorbed by Trees}

The $\mathrm{N}$ and $\mathrm{P}$ losses as a result of the two harvest rotations (2004 and 2012) exceeded the inputs from fertilization and atmospheric deposition, resulting in a net loss of $\mathrm{N}$ and $\mathrm{P}$ from the site. In this period, the net $\mathrm{N}$ balance for $\mathrm{ReM}+\mathrm{F}, \mathrm{ACR}+\mathrm{F}, \mathrm{ReR}+\mathrm{F}$, and ACR $-\mathrm{N}$ treatments was $-255,-516$, -787 , and $-770 \mathrm{~kg} \cdot \mathrm{ha}^{-1}$, respectively. With regards to $\mathrm{P}$, there was also a negative net balance of -24 , $-48,-70$, and $-128 \mathrm{~kg} \cdot \mathrm{ha}^{-1}$ in the ReM + F, ACR + F, ReR + F, and ACR - P treatments, respectively. The net balance was positive only for $S$, with approximately $+120 \mathrm{~kg} \cdot \mathrm{ha}^{-1}$ for all treatments with the exception of the ACR - N treatment, which contained a net balance of $-128 \mathrm{~kg} \cdot S \cdot \mathrm{ha}^{-1}$ (Table 4). $\mathrm{N}$ inputs through biological fixation are unlikely due to the absence of $\mathrm{N}$-fixing weeds. In addition, one should not expect inputs of $\mathrm{N}$ from rock weathering as the soil was highly weathered (Ferralsol). The difference between nutrient losses due to harvesting and nutrients supplied via fertilization and atmospheric deposition must be made up for with nutrients absorbed from soil pools.

Table 4. Nutrient balance in two Eucalyptus grandis rotations under different timber harvest intensities and fertilizer applications.

\begin{tabular}{|c|c|c|c|}
\hline Treatment & $\mathrm{N}\left(\mathrm{kg} \cdot \mathrm{ha} \mathbf{a}^{-1}\right)$ & $P\left(k g \cdot h a^{-1}\right)$ & $\mathrm{S}\left(\mathrm{kg} \cdot \mathrm{ha}^{-1}\right)$ \\
\hline \multicolumn{4}{|c|}{ Net Nutrient Balance ${ }^{1}$} \\
\hline $\operatorname{ReM}+\mathrm{F}$ & -255 & -24 & 148 \\
\hline $\mathrm{ACR}+\mathrm{F}$ & -516 & -48 & 135 \\
\hline $\operatorname{ReR}+\mathrm{F}$ & -787 & -70 & 111 \\
\hline $\mathrm{ACR}-\mathrm{N}$ & -770 & -48 & -128 \\
\hline $\mathrm{ACR}-\mathrm{P}$ & -490 & -128 & 141 \\
\hline \multicolumn{4}{|c|}{ Difference in Soil Nutrients Stocks from 2004 to $2012(0-20 \mathrm{~cm})$} \\
\hline $\operatorname{ReM}+\mathrm{F}$ & -164 & 0.8 & -1.1 \\
\hline $\mathrm{ACR}+\mathrm{F}$ & -189 & -0.4 & -1.3 \\
\hline $\operatorname{Re} \mathrm{R}+\mathrm{F}$ & -192 & -0.5 & -2.5 \\
\hline $\mathrm{ACR}-\mathrm{N}$ & -219 & -0.9 & -1.4 \\
\hline $\mathrm{ACR}-\mathrm{P}$ & -189 & -2.0 & 4.0 \\
\hline
\end{tabular}

1 Differences between the inputs by fertilizer application and atmospheric deposition with the harvest outputs (Table 3 and Figure 1).

From 2004 to 2012, soil $\mathrm{N}$ stocks declined in the 0-20 cm layer for all treatments (Figure 1). The ReR + F treatment was the most affected among the treatments due to the elevated nutrient outputs by harvest. For the ACR $-\mathrm{N}$ treatment, this was due to the small quantity of $\mathrm{N}$ applied via fertilization. In the ReM + F treatment, the 0-20 cm layer was responsible for providing $65 \%$ of the difference in the balance of soil N. The 0-20 cm layer was responsible for providing $35 \%$ of the difference in net soil $\mathrm{N}$ balance for the ACR treatments and 24\% for the ReR + F treatment (Figure 1 and Table 4). The maintenance of harvest residues on the soil increases soil $\mathrm{C}$ and $\mathrm{N}$ pools-especially in labile fractions - thereby increasing the capacity of upper layers to provide $\mathrm{N}$ to plants [14-16,30]. The remaining difference possibly came from deeper layers of the soil profile and factors such as biological fixation by symbiotic associations which were not examined in this study [40]. Despite the large difference in the nutrient outputs between $\mathrm{ReM}+\mathrm{F}$ and $\mathrm{ReR}+\mathrm{F}$ treatments (more than $500 \mathrm{~kg} \cdot \mathrm{ha}^{-1}$ in the net balance), no differences in the $\mathrm{N}$ stocks between these treatments were found in the deeper layers of the soil $(20-200 \mathrm{~cm})$. More research is necessary in order to fully understand the additional sources of $\mathrm{N}$ in such highly weathered, tropical forests.

Little reduction was observed in the stocks of available $\mathrm{P}$ in the $0-20$ layer (Figure 1 ). The ACR - P treatment presented the highest reduction $\left(2 \mathrm{~kg} \cdot \mathrm{ha}^{-1}\right)$, while the $\mathrm{ReM}+\mathrm{F}$ treatment presented a slight increase. This happened even with the negative balance of the nutrient for all treatments evaluated. 
No reduction in soil $\mathrm{P}$ below $40 \mathrm{~cm}$ depth was observed in 2016 (Figure 2). The small reduction in $\mathrm{P}$ content contradicts the highly negative net balance of this nutrient across treatments. $\mathrm{P}$ balance for all treatments was $-60 \mathrm{~kg} \cdot \mathrm{ha}^{-1}$ on average. The ACR $-\mathrm{P}$ treatment had a deficit of $-128 \mathrm{~kg} \cdot \mathrm{ha}^{-1}$ while the reduction was only $6 \mathrm{~kg} \cdot \mathrm{ha}^{-1}$ from $0-200 \mathrm{~cm}$ of soil depth. This discrepancy suggests that the Eucalyptus trees take up soil $\mathrm{P}$ hidden in fractions not extracted by the traditional resin method of analysis. Eucalyptus species can uptake organic and inorganic P fractions by phosphatase and exudation of low molecular mass acids [41]. More studies are necessary to clarify the complete origin of $\mathrm{P}$ absorbed by trees.

Even with a positive net balance of $\mathrm{S}$ stocks in the soil (Table 4), a small reduction was observed in the stocks of the nutrient when comparing the evaluations in 2004 and 2012. This is due to the elevated mobility of the element in the soil, especially in the upper layers [42], along with its consequent migration to and accumulation in the $40-100 \mathrm{~cm}$ layer (Figure 2) where it will adsorb to positive charges on soil surfaces exposed by losses of OM [39].

\subsection{Management Considerations}

Despite the small effect of whole-tree harvest on the soil nutrient stocks described by many authors [4,14,29-33], this and other studies emphasize the importance of the maintenance of forest residues on the soil, especially in tropical sites with low buffer capacity soils, high productivity, and short cycle plantations [14,16,29-31,33]. In these sites, removal of forest residues can result in loss of wood productivity of up to $40 \%$ due to the low nutrient pools remaining in the soil [16].

In the past several years, increasing demands for the use of forest residues for bioenergy purposes has grown in Brazil. Models for the utilization of these residues are based on research in temperate regions, where soils often have higher buffer capacities and higher organic $C$ contents. This study shows that in tropical conditions the use of forest residues for bioenergy purposes should be carefully considered, taking into account the unique conditions of each site. On steep sites and/or those with low buffer capacity, all forest residues should be retained on the soil in order to avoid soil erosion [43] and depletion of soil nutrient pools $[14,16,29,30,33,41]$. In sites with favorable conditions for residue removal, preference should be given to the coarse residues due to their high caloric power and reduced nutrient concentration. With the removal of forest residues, the application of high rates of fertilizer is necessary in order to avoid productivity losses and to ensure the sustainability of the silviculture system.

The high negative net balance, especially for $\mathrm{N}$ and $\mathrm{P}$, and the relative low reduction in the availability of these nutrients in the soil draws attention to two main points. First, more attention should be given to production sustainability, mainly in sites harvested in the whole-tree harvest system. Second, more studies should be implemented to better understand the contributions of organic and inorganic (mainly to P) fractions of low lability on the supply of nutrients to trees. Our results and others $[29,41]$ suggest that Eucalyptus trees can access $P$ fractions not identified by traditional soil analysis methods. Regarding $\mathrm{N}$ concentrations, even with high harvest outputs (more than $500 \mathrm{~kg} \cdot \mathrm{ha}^{-1}$ in each crop rotation) no response to $\mathrm{N}$ application by fertilization was found in terms of wood productivity in Brazilian conditions [28]. More research is essential to better understand the sources and the cycle of this nutrient within tropical soil-plant systems.

\section{Conclusions}

It was observed a reduction in organic $\mathrm{C}$, total $\mathrm{N}$, available $\mathrm{P}$ and $\mathrm{S}$ stocks in the whole tree harvest and the whole tree plus litter treatments, especially at $0-40 \mathrm{~cm}$. The balances of $\mathrm{N}$ and $\mathrm{P}$ in the two rotations of the experiment were negative in all treatments, with even lower values when whole tree and litter were removed or when no fertilizer was applied. The reduction in the total $\mathrm{N}$ and available $\mathrm{P}$ stocks in the soil explain around $50 \%$ of the negative balance observed for these nutrients; the source of the remaining $50 \%$ was not determined for this study. Our results indicate that $\mathrm{N}$ and $\mathrm{P}$ soil pools play an important role in forest nutrition; the reduction in these pools can possibly affect the sustainability 
of the production system in the long term. More research is necessary in order to better understand the balance of nutrients within the soil-plant system.

Acknowledgments: The authors would like to thank University of Washington/EUA, Experimental Station of Forest Sciences of Itatinga/Brazil, University of Sao Paulo/Brazil and FAPESP/Brazil (Processes: 2010/16623-9 and 2014/15876-1) for the financial support and for field collections.

Author Contributions: M.L.C.M. and J.H.T.R. wrote the manuscript as well as performed the soil sampling, and modeled and interpreted the results. A.R., J.C.A.J., A.V.F., J.N.J., and S.M.-C. helped on the interpretation of some of the results. R.R. and J.L.d.M.G. gave suggestions on the modeling and interpretation of the results. R.F.A. and M.d.C.P. performed the laboratory analysis.

Conflicts of Interest: The authors declare no conflict of interest.

\section{References}

1. Schlesinger, W.H.; Bernhardt, E.S. Biogeochemistry: An Analysis of Global Change, 3rd ed.; Elsevier: New York, NY, USA, 2013; pp. 1-664.

2. Jobbagy, E.; Jackson, R. The distribution of soil nutrients with depth: Global patterns and the imprint of plants. Biogeochemistry 2001, 53, 51-77. [CrossRef]

3. Vitousek, P.M.; Naylor, R.; Crews, T.; David, M.B.; Drinkwater, L.E.; Holland, E. Nutrient imbalances in agricultural development. Science 2009, 324, 1519-1520. [CrossRef] [PubMed]

4. Du Toit, B. Effects of site management on growth, biomass partitioning and light use efficiency in a young stand of Eucalyptus grandis in South Africa. For. Ecol. Manag. 2008, 255, 2324-2336. [CrossRef]

5. Gonçalves, J.L.N.; Stape, J.L.; Wichert, M.C.P.; Gava, J.L. Conservação e Cultivo de Solos Para Plantações de Florestas (Soil Conservation and Cultivation for Forest Production); Instituto de Pesquisas e Estudos Florestais (IPEF): Piracicaba, (SP), Brazil, 2002; pp. 131-204.

6. Corbeels, M.; McMurtrie, R.E.; Pepper, D.A.; Mendham, D.S.; Grove, T.S.; O'Connell, A.M. Long-term changes in productivity of Eucalyptus plantations under different harvest residues and nitrogen and management practices: A modeling analysis. For. Ecol. Manag. 2005, 217, 1-18. [CrossRef]

7. Compton, J.E.; Cole, D.W. Phosphorus cycling and soil P fractions in Douglas-fir and red alder stands. For. Ecol. Manag. 1998, 110, 101-112. [CrossRef]

8. Hall, S.J.; Matson, P.A. Nutrient status of tropical rainforest influences soil $\mathrm{N}$ dynamics after $\mathrm{N}$ additions. Ecol. Monogr. 2003, 73, 107-129. [CrossRef]

9. Walmsley, J.D.; Jones, D.L.; Reynolds, B.; Price, M.H.; Healey, J.R. Whole tree harvesting can reduce second rotation forest productivity. For. Ecol. Manag. 2009, 257, 1104-1111. [CrossRef]

10. Jones, H.; Beets, P.; Kimberley, M.; Garrett, M. Harvest residue management and fertilization effect on soil carbon and nitrogen in a 15-year old Pinus radiata plantation forest. For. Ecol. Manag. 2011, 262, 339-347. [CrossRef]

11. Rocha, J.H.T.; Marques, E.R.G.; Goncalves, J.L.M.; Hubner, A.; Brandini, C.B.; Ferraz, A.V.; Moreira, R.M. Decomposition rates of forest residues and soil fertility after clear-cutting of Eucalyptus grandis stands in response to site management and fertilizer application. Soil Use Manag. 2016. [CrossRef]

12. $\mathrm{Xu}, \mathrm{X}$; Luo, $\mathrm{Y}$; Zhou, J. Carbon quality and the temperature sensitivity of soil organic carbon in a tallgrass prairie. Soil Biol. Biochem. 2012, 50, 142-148. [CrossRef]

13. Mendham, D.S.; White, D.A.; Battaglia, M.; McGrath, J.F.; Short, T.M.; Ogden, G.N.; Kinal, J. Soil water depletion and replenishment during first- and early second-rotation Eucalyptus globulus plantations with deep soil profiles. Agric. For. Meteorol. 2011, 151, 1568-1579. [CrossRef]

14. Nambiar, E.K.S.; Harwood, C.E. Productivity of acacia and eucalypt plantations in Southeast Asia 1. Biophysical determinants of production: Opportunities and challenges. Intern. For. Rev. 2014, 16, 225-248.

15. Achat, D.L.; Deleuze, C.; Landmann, G.; Pousse, N.; Ranger, J.; Augusto, L. Quantifying consequences of removing harvesting residues on forest soils and tree growth-A meta-analysis. For. Ecol. Manag. 2015, 348, 124-141. [CrossRef]

16. Rocha, J.H.T.; Goncalves, J.L.M.; Gava, J.L.; Godinho, T.O.; Melo, E.S.A.C.; Bazani, J.H.; Hubner, A.; Arthur Junior, J.C.; Wichert, M.P. Forest residue maintenance increased the wood productivity of a Eucalyptus plantation over two short rotations. For. Ecol. Manag. 2016, 379, 1-10. [CrossRef] 
17. Peng, Y.; Thomas, S.C.; Tian, D. Forest management and soil respiration: Implications for carbon sequestration. Environ. Rev. 2008, 16, 93-111. [CrossRef]

18. Holub, S.M.; Terry, T.A.; Harrington, C.A.; Harrison, R.B.; Meade, R. Tree growth ten years after residual biomass removal, soil compaction, tillage, and competing vegetation control in a highly productive Douglas-fir plantation. For. Ecol. Manag. 2013, 305, 60-66. [CrossRef]

19. Alvares, C.A.; Stape, J.L.; Sentelhas, P.C.; Goncalves, J.L.M.; Sparovek, G. Koppen's climate classification map for Brazil. Meteorol. Z. 2013, 22, 711-728. [CrossRef]

20. Van Raij, B.; Andrade, J.C.; Cantarella, H.; Quaggio, J.A. Análise Química Para Avaliação da Fertilidade de Solos Tropicais (Chemical Analysis for the Evaluation of Fertility in Tropical Soils); Instituto Agronomico de Campinas (IAC): Campinas, (SP), Brazil, 2001; pp. 1-58.

21. Ribeiro, J.F.; Walter, B.M.T. Fitofisionomias do Bioma Cerrado. Phytophisiognomy of Cerrado biome. In Cerrado: Ambiente e Flora (Cerrado: Environment and Flora); Sano, S.M., Almeida, S.P., Eds.; Embrapa: Brasilia, Brazil, 1998; pp. 1-556.

22. Nelson, D.W.; Sommers, L.E. Total carbon, organic carbon, and organic matter. In Methods of Soil Analysis. Part 3. Chemical Methods; SSSA Book Series No. 5; Sparks, D.L, Ed.; Soil Science Society of America/SSSA and American Society of Agronomy (ASA): Madison, WI, USA, 1996; pp. 961-1010.

23. Walkley, A.; Black, I.A. An examination of the Degtjareff method for determining soil organic matter, and a proposed modification of the chromic acid titration method. Soil Sci. 1934, 37, 29-38. [CrossRef]

24. Schumacher, F.X.; Hall, F.D.S. Logarithmic expression of timber-tree volume. J. Agric. Res. 1933, 47, 719-734.

25. Malavolta, E.; Vitti, G.C.; Oliveira, A.S. Avaliação do Estado Nutricional das Plantas: Princípios e Aplicações (Evaluation of Nutritional Condition of Plants: Principles and Application); Associação Brasileira para Pesquisa da Potassa e do Fosfato: Piracicaba, Brazil, 1989; pp. 1-201.

26. Zar, J.H. Biostatistical Analysis, 5th ed.; Pearson Education Ltd.: DeKalb, IL, USA, 2010.

27. Hubner, A. Ciclagem de Nutrientes e Produtividade de Madeira em Povoamento de Eucalyptus Grandis Sob Diferentes Manejos de Resíduos Florestais e Fertilização Mineral (Nutrient Cycling and Growth in Eucalyptus Grandis Plantation under Different Forest Residues Management and Fertilization). Ph.D. Thesis, ESALQ-USP, Piracicaba, Brazil, 2015.

28. Pulito, A.P.; Goncalves, J.L.M.; Smethurst, P.J.; Arthur Junior, J.C.; Alvares, C.A.; Rocha, J.H.T.; Hubner, A.; Moraes, L.F.; Miranda, A.C.; Kamogawa, M.Y.; et al. Available nitrogen and responses to nitrogen fertilizer in Brazilian Eucalypt plantations on soils of contrasting textures. Forests 2015, 6, 973-991. [CrossRef]

29. Laclau, J.-P.; Ranger, J.; Goncalves, J.L.M.; Maquere, V.; Krusche, A.V.; M'Bou, A.T.; Nouvellon, Y.; Saint-Andre, L.; Bouillet, J.-P.; Piccolo, M.D.C. Biogeochemical cycles of nutrients in tropical Eucalyptus plantations Main features shown by intensive monitoring in Congo and Brazil. For. Ecol. Manag. 2010, 259, 1771-1785. [CrossRef]

30. Mendham, D.S.; Ogden, G.N.; Short, T.; O'Connell, T.M.; Grove, T.S.; Rance, S.J. Repeated harvest residue removal reduces E. globulus productivity in the 3rd rotation in south-western Australia. For. Ecol. Manag. 2014, 329, 279-286. [CrossRef]

31. Mendham, D.S.; O'Connell, A.M.; Grove, T.S.; Rance, S.J. Residue management effects on soil carbon and nutrient contents and growth of second rotation eucalypts. For. Ecol. Manag. 2003, 181, 357-372. [CrossRef]

32. Huang, Z.; He, Z.; Wan, X.; Hu, Z.; Fan, S.; Yang, Y. Harvest residue management effects on tree growth and ecosystem carbon in a Chinese fir plantation in subtropical China. Plant Soil 2013, 364, 303-314. [CrossRef]

33. Kumaraswamy, S.; Mendham, D.S.; Grove, T.S.; O'Connell, A.M.; Sankaran, K.V.; Rance, S.J. Harvest residue effects on soil organic matter, nutrients and microbial biomass in eucalypt plantations in Kerala, India. For. Ecol. Manag. 2014, 328, 140-149. [CrossRef]

34. Moreno-Fernandez, D.; Dias-Pines, E.; Barbeito, I.; Sanchez-Gonzalez, M.; Montes, F.; Rubio, A.; Canellas, I. Temporal carbon dynamics over the rotation period of two alternative management systems in Mediterranean mountain Scots pine forests. For. Ecol. Manag. 2015, 348, 186-195. [CrossRef]

35. Rocha, J.H.T. Reflexos do Manejo de Resíduos Florestais na Produtividade, Nutrição e Fertilidade do Solo em Plantações de Eucalyptus grandis (Implications of Forest Harvest Residues Management on the Productivity, Nutrition and Soil Fertility in Eucalyptus grandis Plantation in Brazil). Master's Thesis, ESALQ-USP, Piracicaba, Brazil, 2014.

36. Vanguelova, E.; Pitman, R.; Luiro, J.; Helmisaari, H.-S. Long-term effects of whole tree harvesting on soil carbon and nutrient sustainability in the UK. Biogeochemistry 2010, 101, 43-59. [CrossRef] 
37. Rocha, J.H.T.; Franci, A.F.; Gonçalves, J.L.M. Effect of forest residue management on fine roots density in an Eucalyptus grandis plantation. "Luiz de Queiroz" College of Agriculture, University of São Paulo: Piracicaba, Brazil, Unpublished data. 2016.

38. Smolander, A.; Kitunen, V.; Tamminen, P.; Kukkola, M. Removal of logging residue in Norway spruce thinning stands: Long-term changes in organic layer properties. Soil Biol. Biochem. 2010, 42, 1222-1228. [CrossRef]

39. Brady, N.C.; Weil, R.R. The Nature and Properties of the Soil, 14th ed.; Bookmam: DeKalb, IL, USA, 2013; pp. 1-716.

40. Silva, M.D.S.; Paula, T.D.; Moreira, B.C.; Carolino, M.; Cruz, C.; Bazzolli, D.M.S.; Silva, C.C.; Kasuya, M.C.M. Nitrogen-Fixing Bacteria in Eucalyptus globulus Plantations. PLoS ONE 2014, 9, e111313. [CrossRef] [PubMed]

41. Costa, M.G.; Gama-Rodrigues, A.C.; Gonçalves, J.L.M.; Gama-Rodrigues, E.F.; Sales, M.V.S.; Aleixo, S. Labile and non-labile fractions of phosphorus and its transformations in soil under Eucalyptus plantations, Brazil. Forests 2016, 7, 1-15. [CrossRef]

42. Bissani, C.A.; Tedesco, M.J. O enxofre no solo (Sulphur in the soil). In Reunião Brasileira de Fertilidade do Solo, 17nd ed.; Borkert, C.M., Lantmann, A.F., Eds.; EMBRAPA/IAPAR/SBCS: Londrina, Brazil, 1988; pp. 11-29.

43. Candido, B.M.; Silva, M.L.N.; Curi, N.; Batista, P.V.G. Water erosion post-planting in eucalyptus forests in the Parana river basin, in the eastern Mato Grosso do Sul. Revista Brasileira De Ciencia Do Solo 2014, 38, $1565-1575$.

(C) 2016 by the authors; licensee MDPI, Basel, Switzerland. This article is an open access article distributed under the terms and conditions of the Creative Commons Attribution (CC-BY) license (http://creativecommons.org/licenses/by/4.0/). 